Article

\title{
Manipulatable Interface Electric Field and Charge Transfer in a 2D/2D Heterojunction Photocatalyst via Oxygen Intercalation
}

\author{
Minyeong Je ${ }^{1,2}$, Eun Seob Sim ${ }^{2}$, Jungwook Woo ${ }^{2}$, Heechae Choi ${ }^{1, *(\mathbb{D})}$ and Yong-Chae Chung ${ }^{2, *}$ \\ 1 Theoretical Materials \& Chemistry Group, Institute of Inorganic Chemistry, University of Cologne, \\ Greinstr. 6, 50939 Cologne, Germany; mje@uni-koeln.de \\ 2 Division of Materials Science and Engineering, Hanyang University, 222 Wangsimni-ro, Seongdong-gu, \\ Seoul 04763, Korea; ses1691@gmail.com (E.S.S.); dkdlfjqmdb20@gmail.com (J.W.) \\ * Correspondence: h.choi@uni-koeln.de (H.C.); yongchae@hanyang.ac.kr (Y.-C.C.)
}

Received: 26 March 2020; Accepted: 22 April 2020; Published: 25 April 2020

\begin{abstract}
Charge separation is the most important factor in determining the photocatalytic activity of a 2D/2D heterostructure. Despite the exclusive advantages of 2D/2D heterostructure semiconductor systems such as large surface/volume ratios, their use in photocatalysis is limited due to the low efficiency of charge separation and high recombination rates. As a remedy for the weak interlayer binding and low carrier transport efficiency in 2D/2D heterojunctioned semiconductors, we suggested an impurity intercalation method for the $2 \mathrm{D} / 2 \mathrm{D}$ interface. $\mathrm{PtS}_{2} / \mathrm{C}_{3} \mathrm{~N}_{4}$, as a prototype heterojunction material, was employed to investigate the effect of anion intercalation on the charge separation efficiency in a 2D/2D system using density functional theory. With oxygen intercalation at the $\mathrm{PtS}_{2} / \mathrm{C}_{3} \mathrm{~N}_{4}$ interface, a reversed and stronger localized dipole moment and a built-in electric field were induced in the vertical direction of the $\mathrm{PtS}_{2} / \mathrm{C}_{3} \mathrm{~N}_{4}$ interface. This theoretical work suggests that the anion intercalation method can be a way to control built-in electric fields and charge separation in designs of 2D/2D heterostructures that have high photocatalytic activity.
\end{abstract}

Keywords: density functional theory; photocatalytic water splitting; graphitic carbon nitrides; platinum disulfides; 2D/2D heterostructure; intercalation

\section{Introduction}

With the increasing energy demand, energy conversion and storage are important key factors to meet the demands of humans. At the same time, the energy crisis and environmental pollution problems come one after another because the burning of fossil fuels produces a huge amount of $\mathrm{CO}_{2}$. Therefore, renewable energy sources have received intensive attention as an alternative to non-renewable fossil fuels [1-3]. Solar energy conversion to hydrogen and hydrocarbon fuels using photocatalysts are considered to be a very promising renewable energy resources $[4,5]$, however, eco-friendly hydrogen production from solar energy is only $5 \%$ of the total commercial hydrogen production [6]. To increase hydrogen production by renewable energy sources, the semiconductor-based photocatalyst has received considerable interest in water splitting and pollutant degradation, such as $\mathrm{CO}_{2}$ reduction $[7,8]$. However, the most widely used photocatalysts such as metal oxide and precious metals are limited because of the high cost and the band gap within the ultraviolet region [9-11]. Therefore, semiconductor photocatalysts require a suitable photocatalytic system for efficient charge separation for electron-hole pairs [12-14].

Graphitic carbon nitrides $\left(\mathrm{C}_{3} \mathrm{~N}_{4}\right)$ have attracted attention for hydrogen and oxygen evolution as a water splitting photocatalyst due to their low cost, easy fabrication, and high chemical and thermal stability $[11,15,16]$. In particular, the band gap of $C_{3} N_{4}(2.70 \mathrm{eV})$ is appropriate for a photocatalyst 
because it covers both water reduction and oxidation [17]. However, $\mathrm{C}_{3} \mathrm{~N}_{4}$ shows poor photocatalytic efficiency induced by the fast recombination of the electron-hole pairs. Thus, to solve these problems, many studies have been conducted using a wide variety of modification strategies such as co-catalyst incorporation, 2D/2D heterostructures, and impurity doping [18-21].

Among the various modification strategies in the photocatalyst, the fabrication of $2 \mathrm{D} / 2 \mathrm{D}$ heterojunctions based on monolayer 2D materials has been demonstrated as an effective approach toward high performance photocatalysts. However, due to the large interface region, 2D/2D heterojunctions often exhibit a high charge mobility and low charge recombination rates [22]. To solve this problem, many researchers are trying to find a $2 \mathrm{D} / 2 \mathrm{D}$ heterostructure with the appropriate photocatalytic system. In the case of $\mathrm{C}_{3} \mathrm{~N}_{4} / 2 \mathrm{D}$ heterostructures, it was found that the photocatalytic systems such as Z-scheme and type-II vary according to the types of materials [23,24]. Therefore, using density functional theory (DFT), systematic research focusing on the rational design and construction of $C_{3} \mathrm{~N}_{4} / 2 \mathrm{D}$ interface is necessary for readers to better understand the principles of 2D photocatalysts.

The charge separation is a very important factor for photocatalytic water splitting $[25,26]$. In particular, in $2 \mathrm{D} / 2 \mathrm{D}$ heterostructures for photocatalyst systems, the driving force for charge separation is the energy level difference of the electrons and holes built by the band alignment of the heterostructure [27-29]. In other words, if the exchange of electrons and holes between the two layers is more active, it is more effective to separate the charge at the interface. However, charge flow across the two layers is restricted in $2 \mathrm{D} / 2 \mathrm{D}$ heterostructures because the nature of its interface is commonly a van der Waals (vdW) interaction [30]. This indicates that 2D/2D heterostructures still suffer from low efficiency in charge separating and transferring oriented charges [31,32]. According to previous studies, it is reported that charge separation at interfaces of $\mathrm{vdW}$ heterostructures can be promoted through impurity intercalation $[30,33]$. This means that impurity intercalation will play an important role when a 2D heterostructure strategy is adopted in $\mathrm{PtS}_{2} / \mathrm{C}_{3} \mathrm{~N}_{4}$ heterostructures for increasing photogeneration of electron-hole pairs throughout its lifetime. Among the various impurity atoms, $\mathrm{O}$ as the impurity for intercalation was chosen because it does not influence the structure of $\mathrm{g}-\mathrm{C}_{3} \mathrm{~N}_{4}$, but improves the charge separation [34,35]. Therefore, it must be confirmed that it is possible to use a $\mathrm{PtS}_{2} / \mathrm{O} / \mathrm{C}_{3} \mathrm{~N}_{4}$ heterostructure as a photocatalyst through a theoretical approach.

Among the various 2D materials, transition metal dichalcogenide (TMD) is widely used as a co-catalyst in a photocatalyst due to its hydrogen evolution reaction (HER) ability and the ease of controlling its electronic properties [36-39]. $\mathrm{C}_{3} \mathrm{~N}_{4} / \mathrm{TMD}$ heterostructures such as $\mathrm{C}_{3} \mathrm{~N}_{4} / \mathrm{MoS}_{2}$ and $\mathrm{C}_{3} \mathrm{~N}_{4} / \mathrm{SnS}_{2}$ afford a high photocatalytic activity [40-42]. Group-10 TMD has been reported as a potentially promising photocatalyst, electrocatalyst, and opto-electronic device because of its unique properties [43-45]. Lattice mismatches must be considered in the heterostructure because they are associated with compressive or tensile stress, affecting the electronic properties [46,47]. Among the Group-10 TMDs, platinum disulfides $\left(\mathrm{PtS}_{2}\right)$ showed a low lattice mismatch between $2 \times 2 \mathrm{C}_{3} \mathrm{~N}_{4}$ and $\mathrm{PtS}_{2}$. In addition, $\mathrm{PtS}_{2}$ has recently been reported to have shown good HER performance and to have the appropriate band gap of $1.8 \mathrm{eV}$ for a photocatalyst [44]. Thus, $\mathrm{PtS}_{2}$ was chosen to avoid other effects such as corrugation, and to see only the effects of the O-intercalation.

Herein, the effect of O-intercalation in the $\mathrm{PtS}_{2} / \mathrm{C}_{3} \mathrm{~N}_{4}$ heterostructure was investigated through density functional theory (DFT) calculations. After O-intercalation at the interface, the charge redistribution trend changed. Due to the changed dipole moment by the electron acceptance between the surface and the $\mathrm{O}$, the direction of the built-in electric field was reversed. The amount of charge transfer increased due to the increase in the strength of the built-in electric field at the interface. In addition, charge separation efficiency was improved as O-intercalation increased. $\mathrm{PtS}_{2} / \mathrm{C}_{3} \mathrm{~N}_{4}$ is a suitable photocatalyst for water splitting because the reduction and oxidation stability is strong. However, $\mathrm{PtS}_{2} / \mathrm{O} / \mathrm{C}_{3} \mathrm{~N}_{4}$ is not suitable for photocatalytic water splitting since its reduction stability is weak. From these results, it is expected that the desired direction of the built-in electric field and the charge separation efficiency can be obtained if the ratio of anion intercalation can be properly controlled. 


\section{Results and Discussion}

As the impurity intercalation of the heterostructure, $\mathrm{O}$ atoms were chosen because previous studies have reported that the photocatalytic performance of monolayer $\mathrm{C}_{3} \mathrm{~N}_{4}$ is enhanced by $\mathrm{O}$ doping [48]. To theoretically examine the stability of the $\mathrm{PtS}_{2} / \mathrm{C}_{3} \mathrm{~N}_{4}$ heterostructure after doping, the intercalation energy $\left(E_{\text {int }}\right)$ of the $\mathrm{PtS}_{2} / \mathrm{Ox} / \mathrm{C}_{3} \mathrm{~N}_{4}$ heterostructure was calculated using Equation (1):

$$
E_{\text {int }}=\frac{1}{n}\left[E\left(P t S_{2} / O x / C_{3} N_{4}\right)-E\left(\frac{P t S_{2}}{C_{3} N_{4}}\right)-\frac{n}{2} E_{O_{2}}\right](x=1.8,3.6,5.4,7.1 \%)
$$

where $E_{P t S_{2} / O_{x} / C_{3} N_{4}}, E_{P t S_{2} / C_{3} N_{4}}$ and $E_{\mathrm{O}_{2}}$ are the total energy of the $P t S_{2} / \mathrm{O}_{\mathrm{x}} / \mathrm{C}_{3} \mathrm{~N}_{4}$, the $\mathrm{PtS} / \mathrm{C}_{3} \mathrm{~N}_{4}$ heterostructure, and the $\mathrm{O}_{2}$, respectively. The $\mathrm{n}$ is the number of $\mathrm{O}$ atoms in the heterostructure. The $E_{\text {int }}$ of the $\mathrm{PtS}_{2} / \mathrm{O}_{1.8 \%} / \mathrm{C}_{3} \mathrm{~N}_{4}$ heterostructure was $-1.78 \mathrm{eV}$. The optimized configuration of the $\mathrm{PtS} 2 / \mathrm{O}_{\mathrm{x}} / \mathrm{C}_{3} \mathrm{~N} 4$ heterostructure is shown Figure $\mathrm{S} 1$. The $\mathrm{E}_{\mathrm{int}}$ of all considered $\mathrm{PtS}_{2} / \mathrm{Ox} / \mathrm{C}_{3} \mathrm{~N}_{4}$ heterostructures is shown in Table S1. Based on these results, we can infer that the $\mathrm{PtS}_{2} / \mathrm{O}_{1.8} \% \mathrm{C}_{3} \mathrm{~N}_{4}$ heterostructure is energetically stable. This means that the $\mathrm{O}$ atoms remain captured between the $\mathrm{C}_{3} \mathrm{~N}_{4}$ and $\mathrm{PtS}_{2}$ layers, rather than diffusing between the layers and recombining to yield $\mathrm{O}_{2}$ or $\mathrm{H}_{2} \mathrm{O}$ gas. The calculated interface binding energy $\left(\mathrm{E}_{\mathrm{b}}\right)$ of the $\mathrm{PtS}_{2} / \mathrm{C}_{3} \mathrm{~N}_{4}$ and the $\mathrm{PtS}_{2} / \mathrm{O}_{1.8} \% / \mathrm{C}_{3} \mathrm{~N}_{4}$ heterostructures was 12.5 and $10 \mathrm{meV} / \AA^{2}$, which was close to the typical vdW-binding energy $\left(13-21 \mathrm{meV} / \AA^{2}\right)$ in previous works $[49,50]$. Hence, the $\mathrm{PtS}_{2} / \mathrm{C}_{3} \mathrm{~N}_{4}$ and $\mathrm{PtS}_{2} / \mathrm{O}_{1.8 \%} / \mathrm{C}_{3} \mathrm{~N}_{4}$ heterostructures belong to a vdW heterostructure.

To explore the charge separation after the O-intercalation in the $\mathrm{PtS}_{2} / \mathrm{C}_{3} \mathrm{~N}_{4}$ heterostructure, the charge density difference and planar-averaged charge density difference of the $\mathrm{PtS}_{2} / \mathrm{C}_{3} \mathrm{~N}_{4}$ and $\mathrm{PtS}_{2} / \mathrm{O}_{\mathrm{X}} / \mathrm{C}_{3} \mathrm{~N}_{4}(\mathrm{X}=1.8,3.6,5.4,7.1 \%)$ heterostructures were calculated. The charge density difference iso-surface can be evaluated with Equation (2):

$$
\Delta \rho(z)=\rho_{\text {total }}-\left(\rho_{C_{3} N_{4}}+\rho_{P t S_{2}}\right)-\rho_{O}
$$

where $\rho_{\text {total }}, \rho_{C_{3} N_{4}}, \rho_{P t S_{2}}$, and $\rho_{X}$ denote the charge densities of the $\mathrm{PtS}_{2} / \mathrm{C}_{3} \mathrm{~N}_{4}$ or $\mathrm{PtS}_{2} / \mathrm{O}_{\mathrm{X}} / \mathrm{C}_{3} \mathrm{~N}_{4}$ heterostructure, the monolayer $\mathrm{C}_{3} \mathrm{~N}_{4}$, the monolayer $\mathrm{PtS}_{2}$, and the $\mathrm{O}$ atom, respectively. It is defined as Equation (3):

$$
\Delta \mathrm{Q}(\mathrm{z})=\int_{-\infty}^{z} \Delta \rho\left(z^{\prime}\right) \mathrm{d} z^{\prime}
$$

The charge density difference and planar charge density difference of the $\mathrm{PtS}_{2} / \mathrm{C}_{3} \mathrm{~N}_{4}$ and the $\mathrm{PtS}_{2} / \mathrm{O}_{1.8 \%} / \mathrm{C}_{3} \mathrm{~N}_{4}$ heterostructures is shown in Figure 1a. The charge density difference iso-surface plots are shown in the inset in Figure 1a. The yellow and sky blue colors indicate the electron accumulation and depletion regions, respectively. The red line of Figure $1 \mathrm{a}$ indicates that the planar-averaged charge density difference of the $\mathrm{C}_{3} \mathrm{~N}_{4} / \mathrm{PtS}_{2}$ (left) and the $\mathrm{PtS}_{2} / \mathrm{O}_{1.8} \% / \mathrm{C}_{3} \mathrm{~N}_{4}$ (right) heterostructures along the $\mathrm{Z}$ direction exhibited charge redistribution. In both the $\mathrm{PtS} \mathrm{S}_{2} / \mathrm{C}_{3} \mathrm{~N}_{4}$ and the $\mathrm{PtS} \mathrm{S}_{2} / \mathrm{O}_{1.8} \% / \mathrm{C}_{3} \mathrm{~N}_{4}$ heterostructures, the charge redistribution mainly occurred around the $\mathrm{PtS}_{2} / \mathrm{C}_{3} \mathrm{~N}_{4}$ heterostructure interface and the charge transferred from the $\mathrm{C}_{3} \mathrm{~N}_{4}$ to the $\mathrm{PtS}_{2}$ layer in the heterostructure. However, in the case of the $\mathrm{PtS}_{2} / \mathrm{C}_{3} \mathrm{~N}_{4}$ heterostructure, little charge transfer showed between the $\mathrm{C}_{3} \mathrm{~N}_{4}$ and $\mathrm{PtS}$. (Figure 1a) This indicates that the $\mathrm{PtS}_{2} / \mathrm{C}_{3} \mathrm{~N}_{4}$ heterostructure shows a low efficiency of separation of photogenerated electron-hole pairs, like other 2D/2D heterostructures [31,51]. Due to the O-intercalation, the $\mathrm{PtS}_{2} / \mathrm{O}_{1.8} / \mathrm{C}_{3} \mathrm{~N}_{4}$ heterostructure effectively boosts the charge separation, better than that of the $\mathrm{PtS}_{2} / \mathrm{C}_{3} \mathrm{~N}_{4}$ heterostructure. The charge transferred from the $\mathrm{PtS}_{2}$ to the $\mathrm{C}_{3} \mathrm{~N}_{4}$ layer at the interface of the $\mathrm{PtS}_{2} / \mathrm{O}_{1.8 \%} / \mathrm{C}_{3} \mathrm{~N}_{4}$ heterostructure, unlike in the $\mathrm{PtS}_{2} / \mathrm{C}_{3} \mathrm{~N}_{4}$ heterostructure. In addition, in the other $\mathrm{O}$ concentration, the direction of charge transfer was the same, and the amount of charge transfer increased (Figure S2). From these results, this study confirmed the impurity intercalation effect on the amount and direction of charge transfer. 

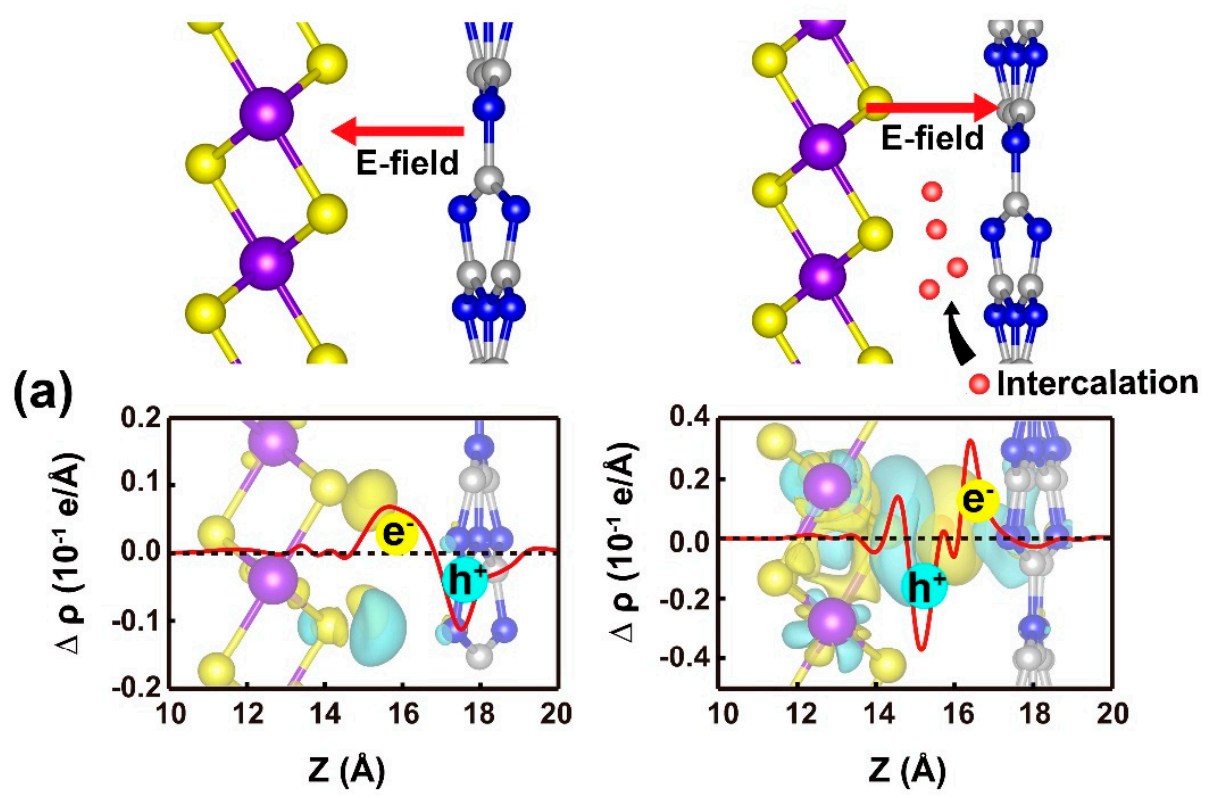

(b)

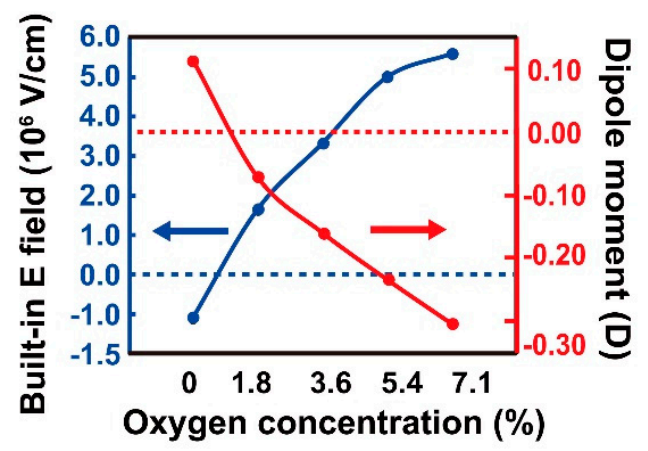

Figure 1. The charge density difference and planar-averaged electron density difference for the (a) $\mathrm{PtS}_{2} / \mathrm{C}_{3} \mathrm{~N}_{4}$ (left) and $\mathrm{PtS}_{2} / \mathrm{O}_{1.8} \% / \mathrm{C}_{3} \mathrm{~N}_{4}$ (right) heterostructures. The yellow and cyan color indicate charge accumulation and depletion, respectively. The iso-values are $0.005 \mathrm{eV} / \AA^{3}$. The purple, yellow, blue, gray, and red colors denote the $\mathrm{Pt}, \mathrm{S}, \mathrm{N}, \mathrm{C}$, and $\mathrm{O}$ atoms, respectively. (b) The built-in electric field and dipole moment of the $\mathrm{PtS}_{2} / \mathrm{O}_{\mathrm{x}} / \mathrm{C}_{3} \mathrm{~N}_{4}(\mathrm{X}=0,1.8,3.6,5.4,7.1 \%)$ heterostructure.

As the built-in electric field at the interface makes an important contribution to charge separation (drifted charge separation) and other charge separation pathways in semiconductors, it must be conceivable [52,53]. In general, the direction of a built-in electric field is induced by the dipole moment [54,55]. Thus, the dipole moment and built-in electric field of the $\mathrm{PtS}_{2} / \mathrm{C}_{3} \mathrm{~N}_{4}$ and the $\mathrm{PtS} \mathrm{S}_{2} / \mathrm{O}_{\mathrm{X}} / \mathrm{C}_{3} \mathrm{~N}_{4}$ heterostructures were calculated, as shown in Figure 1b. Using Equation (3), the dipole moment $(\mu)$ is given by Equation (4)

$$
\mu=\int_{-\infty}^{\infty} z \Delta Q(z) d z
$$

where $z$ indicates the $z$-axis distance. In Figure $1 b$, the red line denotes the dipole moment. The $\mu$ value decreases as $\mathrm{O}$-intercalation increases and the direction of $\mu$ is reversed. As the oxygen is inserted, the direction and strength of the $\mu$ changes because the electrons on the surface of the $\mathrm{PtS}_{2}$ move to the $\mathrm{O}$, resulting in the surface of the $\mathrm{PtS}_{2}$ having a positive charge. This result indicates that the change in dipole moment is caused by the acceptance of electrons occurring between the $\mathrm{PtS}_{2}$ layer and the $\mathrm{O}$, regardless of the interaction between the $\mathrm{O}$ and the $\mathrm{C}_{3} \mathrm{~N}_{4}$ layer. From these results, it can be predicted that a similar dipole moment change will occur due to electron acceptance between the surface and the anion if the other anion as well as the $\mathrm{O}$ are inserted into the 2D/2D heterostructure. Next, a built-in 
electric field was generated at the $\mathrm{PtS}_{2} / \mathrm{C}_{3} \mathrm{~N}_{4}$ and the $\mathrm{PtS}_{2} / \mathrm{O}_{X} / \mathrm{C}_{3} \mathrm{~N}_{4}$ heterostructure. Thus, the built-in electric field was calculated as Equation (5):

$$
\mathrm{E}=\int_{-\infty}^{z} \frac{\Delta \rho\left(z^{\prime}\right)}{\varepsilon_{0}} d z^{\prime}
$$

where $\mathrm{E}$ and $\varepsilon_{0}$ are the built-in electric field, the charge density, and the vacuum permittivity, respectively. $\Delta \rho$ is the charge density difference obtained in Equation (2). The built-in electric field of the $\mathrm{PtS}_{2} / \mathrm{C}_{3} \mathrm{~N}_{4}$ heterostructure $\left(-1.11 \times 10^{6} \mathrm{~V} / \mathrm{cm}\right)$ was smaller than that of the $\mathrm{PtS}_{2} / \mathrm{O}_{1.8} \% / \mathrm{C}_{3} \mathrm{~N}_{4}$ heterostructure $\left(1.64 \times 10^{6} \mathrm{~V} / \mathrm{cm}\right)$. In addition, the direction of the built-in electric field was reversed after O-intercalation in the $\mathrm{C}_{3} \mathrm{~N}_{4} / \mathrm{PtS}_{2}$ heterostructure. As the amount of O-intercalation in the $\mathrm{PtS}_{2} / \mathrm{C}_{3} \mathrm{~N}_{4}$ heterostructure increased, the strength of the built-in electric field increased (Figure $2 \mathrm{~b}$ ). As shown in Figure 2b, as O-intercalation increased, the intensity of the dipole moment and the built-in electric field increased linearly. From these results, it can be inferred that the direction of the built-in electric field can be controlled by adjusting the O-intercalation. This increased built-in electric field indicates that a powerful electrostatic field existed perpendicular to the interface direction. Thus, it can be predicted that the $\mathrm{PtS} 2 / \mathrm{O}_{\mathrm{X}} / \mathrm{C}_{3} \mathrm{~N}_{4}$ heterostructure will show increased photocatalytic activity because the driving force for charge separation provided by the built-in electric field is consequently enhanced, thus leading to significantly increased photocatalytic activity.
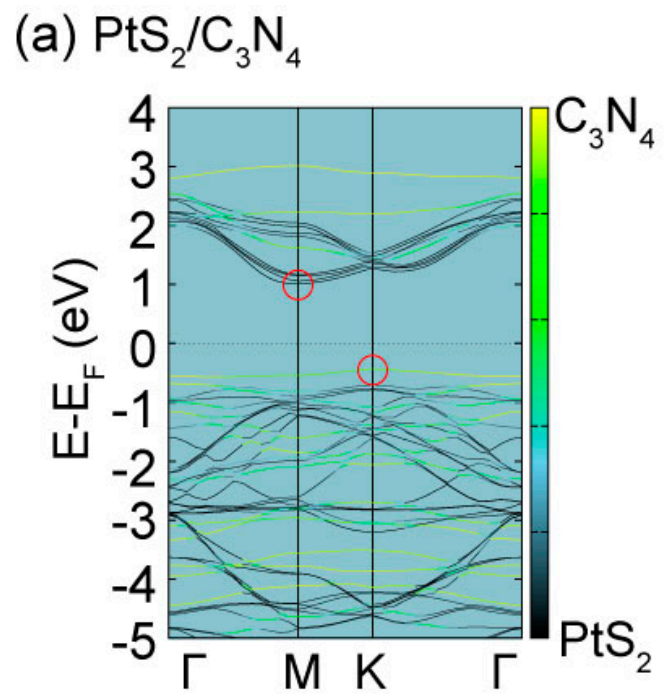
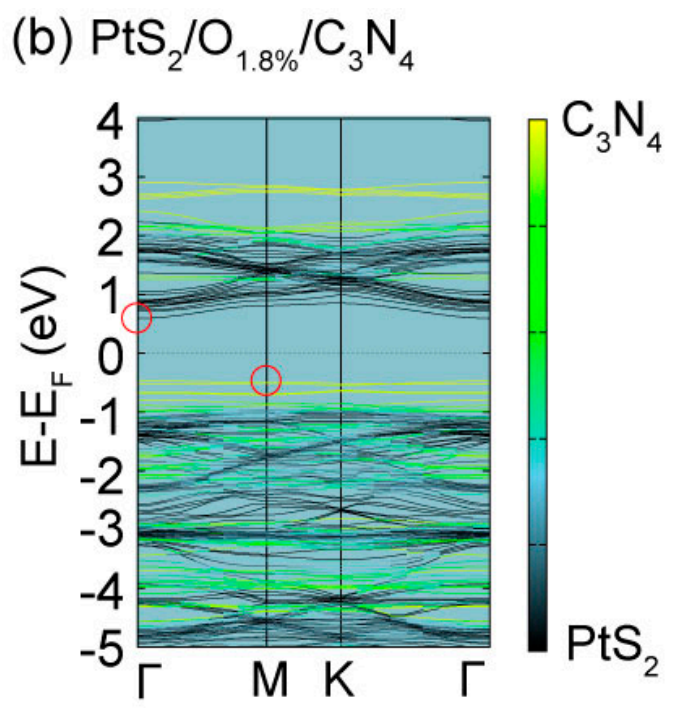

Figure 2. The band structure of (a) the $\mathrm{PtS}_{2} / \mathrm{C}_{3} \mathrm{~N}_{4}$ and (b) the $\mathrm{PtS}_{2} / \mathrm{O}_{1.8} \% / \mathrm{C}_{3} \mathrm{~N}_{4}$ heterostructure, respectively. The contribution of each layer in the band structure of the $\mathrm{PtS}_{2} / \mathrm{C}_{3} \mathrm{~N}_{4}$ heterostructure with or without O-intercalation. The percentages of the contributions of each layer are marked in a different color. The Fermi level was set to zero.

The optimized band structure of the $\mathrm{PtS}_{2} / \mathrm{C}_{3} \mathrm{~N}_{4}$ and the $\mathrm{PtS}_{2} / \mathrm{O}_{1.8} \% / \mathrm{C}_{3} \mathrm{~N}_{4}$ with various $\mathrm{O}$ concentration heterostructures was calculated to confirm the photocatalytic activity (Figure 2). Considering that, in general, the PBE approach underestimates the band gaps $\left(\mathrm{E}_{\mathrm{g}}\right)$, this study used a band structure calculated using the HSE06 method to increase the reliability in the following analyses. The contribution of each layer in the conduction band minimum (CBM) and valence band maximum (VBM) of the $\mathrm{PtS}_{2} / \mathrm{C}_{3} \mathrm{~N}_{4}$ and the $\mathrm{PtS}_{2} / \mathrm{O}_{1.8 \%} / \mathrm{C}_{3} \mathrm{~N}_{4}$ heterostructure was investigated as shown in Figure 3. Since it is generally known that the trends of hybrid functional calculations and normal DFT calculations are not very different, the contribution of each layer in the CBM and the VBM was verified using the band structure of the PBE approach [56]. The contributions of each layer in the $\mathrm{PtS}_{2} / \mathrm{O}_{3.6 \%} / \mathrm{C}_{3} \mathrm{~N}_{4}$, $\mathrm{PtS}_{2} / \mathrm{O}_{5.4 \%} / \mathrm{C}_{3} \mathrm{~N}_{4}$, and $\mathrm{PtS}_{2} / \mathrm{O}_{7.1 \%} / \mathrm{C}_{3} \mathrm{~N}_{4}$ heterostructures are shown in Figure $\mathrm{S} 3$. The $\mathrm{C}_{3} \mathrm{~N}_{4}$ layer in the $\mathrm{PtS}_{2} / \mathrm{C}_{3} \mathrm{~N}_{4}$ heterostructure largely contributed to the VBM, whereas the CBM was dominated by the 
$\mathrm{PtS}_{2}$ layer in the $\mathrm{C}_{3} \mathrm{~N}_{4} / \mathrm{PtS}_{2}$ heterostructure (Figure 2a). In addition, this phenomenon was maintained despite the amount the O-intercalation increased in the $\mathrm{PtS}_{2} / \mathrm{C}_{3} \mathrm{~N}_{4}$ heterostructure (Figure $2 \mathrm{~b}$ and Figure S3). The $\mathrm{PtS}_{2} / \mathrm{C}_{3} \mathrm{~N}_{4}$ heterostructure with and without $\mathrm{O}$-intercalation had staggered gap structures, resulting in Z-scheme or type-II systems. The reason for the difference of heterostructure type is due to the difference in the direction and strength of the built-in electric field caused by the difference in charge redistribution occurring by $\mathrm{O}$-intercalation. From these results, it can be inferred that the electrons and holes will move differently in the $\mathrm{PtS}_{2} / \mathrm{C}_{3} \mathrm{~N}_{4}$ and the $\mathrm{PtS}_{2} / \mathrm{O}_{\mathrm{X}} / \mathrm{C}_{3} \mathrm{~N}_{4}$ heterostructures when visible-light irradiation is absorbed.

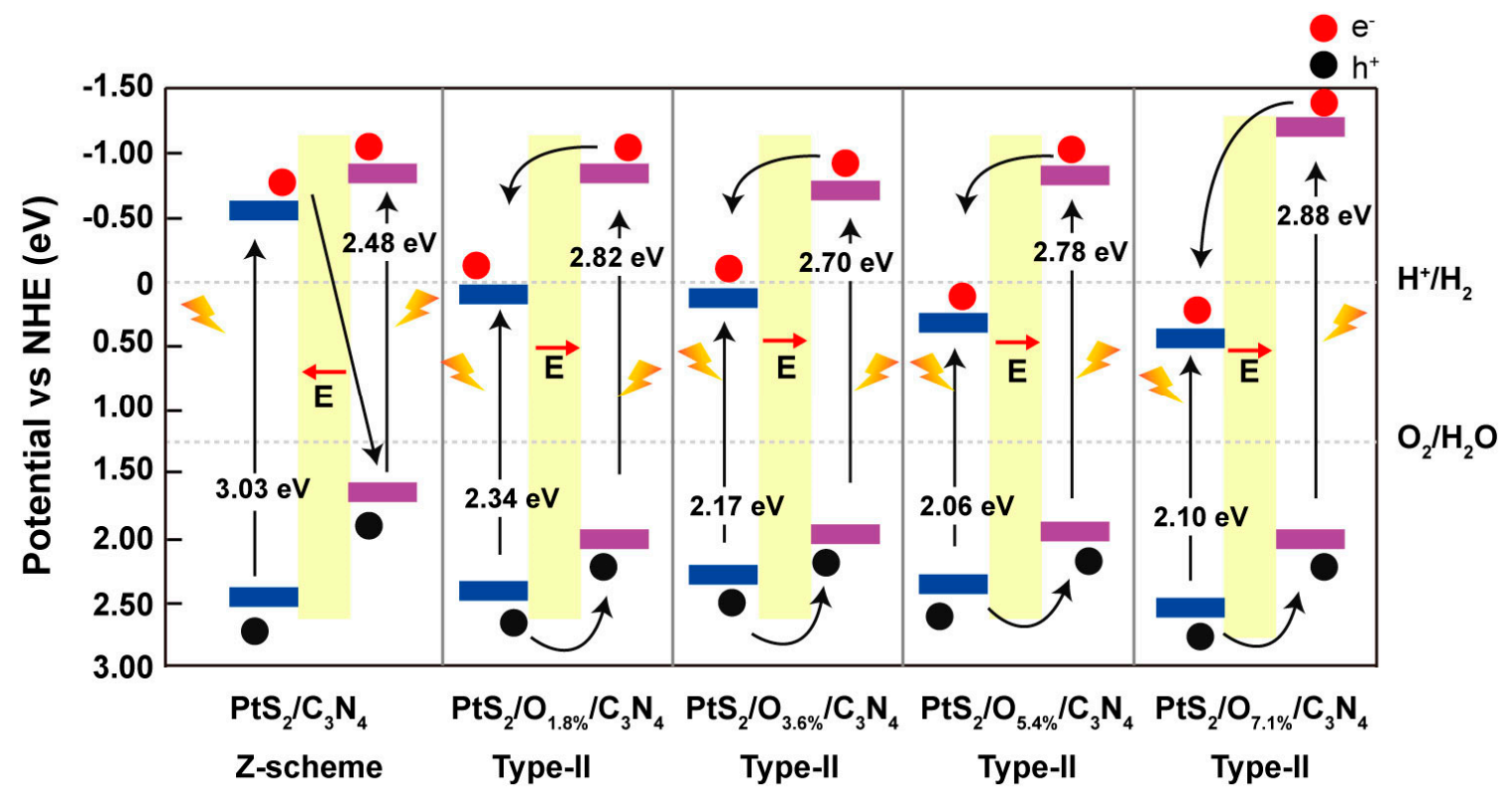

Figure 3. The CBM and VBM potential versus the normal hydrogen electrode of the $\mathrm{PtS}_{2} / \mathrm{C}_{3} \mathrm{~N}_{4}$ and the $\mathrm{PtS}_{2} / \mathrm{O}_{\mathrm{X}} / \mathrm{C}_{3} \mathrm{~N}_{4}(\mathrm{X}=1.8,3.6,5.4,7.1 \%)$ heterostructures using the HSE06 method. E means the built-in electric field.

The band edge position of the $\mathrm{PtS}_{2} / \mathrm{C}_{3} \mathrm{~N}_{4}$ and the $\mathrm{PtS} / \mathrm{O}_{\mathrm{x}} / \mathrm{C}_{3} \mathrm{~N}_{4}$ heterostructures, which is another important factor that determines the performance of photocatalytic water splitting of a semiconductor, was calculated to confirm the redox capability of the $\mathrm{PtS}_{2} / \mathrm{C}_{3} \mathrm{~N}_{4}$ and the $\mathrm{PtS} \mathrm{S}_{2} / \mathrm{O}_{\mathrm{x}} / \mathrm{C}_{3} \mathrm{~N}_{4}$ heterostructures. The potential level vs. the normal hydrogen electrode (NHE) was converted from the vacuum potential level ( $\left.E_{\text {vacuum potential level }}\right)$ using Equation (6) [57]:

$$
E_{\text {potential level vs NHE }}=E^{e}-E_{\text {vacuum potential level }}
$$

where $E^{e}$ is the energy of the free electrons at the hydrogen scale $\left(E^{e}=-4.44 \mathrm{eV}\right)$ and $E_{\text {vacuum potential level }}$ is obtained by the planar-averaged electrostatic potential. To achieve water splitting on the semiconductor, the CBM potential is more negative than the $\mathrm{H}^{+} / \mathrm{H}_{2}$ reduction potential $(0.0 \mathrm{eV})$, and the VBM potential is more positive than the $\mathrm{H}_{2} \mathrm{O} / \mathrm{O}_{2}$ oxidation potential $(1.23 \mathrm{eV})$. Figure 3 shows the charge transfer and band edge position of the $\mathrm{PtS}_{2} / \mathrm{C}_{3} \mathrm{~N}_{4}$ and the $\mathrm{PtS}_{2} / \mathrm{O}_{\mathrm{x}} / \mathrm{C}_{3} \mathrm{~N}_{4}$ heterostructures. The band edge position of the CBM (VBM) potential in the $\mathrm{C}_{3} \mathrm{~N}_{4} / \mathrm{PtS}_{2}$ heterostructure was $-0.56(1.66 \mathrm{eV})$, which was more negative (positive) than the $\mathrm{H}^{+} / \mathrm{H}_{2}$ reduction $\left(\mathrm{O}_{2} / \mathrm{H}_{2} \mathrm{O}\right.$ oxidation) potential. Based on the direction of the built-in electric field, in the case of the $\mathrm{PtS}_{2} / \mathrm{C}_{3} \mathrm{~N}_{4}$ heterostructure, the electrons in the CBM of the $\mathrm{PtS}_{2}$ could transfer to the VBM of the $\mathrm{C}_{3} \mathrm{~N}_{4}$ to combine with holes. In addition, the electrons in the CBM of the $\mathrm{C}_{3} \mathrm{~N}_{4}$ were used to reduce $\mathrm{H}^{+}$to $\mathrm{H}_{2}$, and the holes in the VBM of the $\mathrm{C}_{3} \mathrm{~N}_{4}$ were used to reduce $\mathrm{H}^{+}$to $\mathrm{H}_{2}$. Through this result, it can be inferred that the $\mathrm{PtS}_{2} / \mathrm{C}_{3} \mathrm{~N}_{4}$ heterostructure showed a $\mathrm{Z}$-scheme. In the case of the $\mathrm{PtS}_{2} / \mathrm{O}_{\mathrm{X}} / \mathrm{C}_{3} \mathrm{~N}_{4}$ heterostructure, the electrons transferred from the CBM of the $\mathrm{C}_{3} \mathrm{~N}_{4}$ to the $C B M$ of the $\mathrm{PtS}_{2}$ and the VBM holes of the $\mathrm{PtS}_{2}$ transferred into the VBM of the 
$\mathrm{C}_{3} \mathrm{~N}_{4}$ structure. Thus, $\mathrm{H}^{+} / \mathrm{H}_{2}$ reduction and $\mathrm{O}_{2} / \mathrm{H}_{2} \mathrm{O}$ oxidation occurred in the $\mathrm{CBM}$ of the $\mathrm{PtS}_{2}$ and the VBM of the $\mathrm{C}_{3} \mathrm{~N}_{4}$. In the density of states, there was no defect level caused by $\mathrm{O}$ in the energy gap of the $\mathrm{PtS}_{2}$ and the $\mathrm{C}_{3} \mathrm{~N}_{4}$ (Figure S4). In the case of the $\mathrm{C}_{3} \mathrm{~N}_{4}$ layer, the energy gap increased as $\mathrm{O}$ was inserted at the interface of the $\mathrm{PtS}_{2} / \mathrm{C}_{3} \mathrm{~N}_{4}$ heterostructure. On the other hand, the energy gap of the $\mathrm{PtS}_{2}$ layer decreased. Due to the decreased energy gap of the $\mathrm{PtS}_{2}$, the CBM of the $\mathrm{PtS}_{2}$ was lower than the $\mathrm{O}_{2} / \mathrm{H}_{2} \mathrm{O}$ oxidation potential. Given the decreased energy gap of the $\mathrm{PtS}_{2}$, the CBM of the $\mathrm{PtS}_{2}$ was lower than the $\mathrm{O}_{2} / \mathrm{H}_{2} \mathrm{O}$ oxidation potential. As the monolayer $\mathrm{C}_{3} \mathrm{~N}_{4}$ and monolayer $\mathrm{PtS}_{2}$ had an indirect band gap, $\mathrm{C}_{3} \mathrm{~N}_{4}$ and $\mathrm{PtS}_{2}$ exhibited similar photo absorption efficiency. However, after the intercalation of $\mathrm{O}$ at the interface of the heterostructure, the strength of photo absorption in the $\mathrm{PtS}_{2}$ with a decreased energy gap will increase. From these results, it can be inferred that the strength of photo absorption in the $\mathrm{PtS}_{2}$ will be stronger than that of the $\mathrm{C}_{3} \mathrm{~N}_{4}$ when visible-light irradiation is absorbed. The CBM level was located about $0.09 \mathrm{eV}$ under the $\mathrm{H}^{+} / \mathrm{H}_{2}$ reduction potential. Using the thermal energy at room temperature $(0.026 \mathrm{eV})$, the possibility of $\mathrm{H}^{+} / \mathrm{H}_{2}$ reduction occurring in the $\mathrm{PtS}_{2} / \mathrm{O}_{1.8 \%} / \mathrm{C}_{3} \mathrm{~N}_{4}$ heterostructure was approximately $3 \%$. Thus, it was found that the O-intercalation in the $\mathrm{PtS}_{2} / \mathrm{C}_{3} \mathrm{~N}_{4}$ heterostructures not only enhanced the separation of photogenerated electron-hole pairs, but also changed the direction of the built-in electric field, resulting in the determination of the heterostructure type.

Considering the generally used synthesis conditions of $\mathrm{C}_{3} \mathrm{~N}_{4}$, the possibility of $\mathrm{O}$ intercalation in the $\mathrm{PtS}_{2} / \mathrm{C}_{3} \mathrm{~N}_{4}$ heterostructure was examined theoretically. The relationship between the equilibrium constants $\left(K_{p}\right)$ for reactions and temperatures was considered based on the thermodynamic energy of intercalation formation. The main reactions occurring in the $\mathrm{PtS} / \mathrm{O} / \mathrm{C}_{3} \mathrm{~N}_{4}$ heterostructure can be written as follows:

(1) $\mathrm{O}_{2}$ gas

$$
\mathrm{PtS}_{2} / \mathrm{C}_{3} \mathrm{~N}_{4}+\frac{1}{2} \mathrm{O}_{2}(g) \rightarrow P t S_{2} / O / C_{3} N_{4}
$$

(2) $\mathrm{H}_{2} \mathrm{O}$ gas

$$
\mathrm{PtS}_{2} / \mathrm{C}_{3} \mathrm{~N}_{4}+\mathrm{H}_{2} \mathrm{O}(\mathrm{g}) \rightarrow \mathrm{PtS}_{2} / \mathrm{O} / \mathrm{C}_{3} \mathrm{~N}_{4}+\mathrm{H}_{2}(\mathrm{~g})
$$

The Gibbs energy for interaction is described in Equation (7):

$$
\Delta G_{f}=G_{P t S_{2} / O / C_{3} N_{4}}-G_{P t S_{2} / C_{3} N_{4}}+\sum n_{O} \mu_{O}
$$

where $G_{P t S_{2} / O / C_{3} N_{4}}, G_{P t S_{2} / O / C_{3} N_{4}}, n_{O}$, and $\mu_{O}$ denote the Gibbs energy of the $\mathrm{PtS}_{2} / \mathrm{O} / \mathrm{C}_{3} \mathrm{~N}_{4}$ heterostructure, the Gibbs energy of the $\mathrm{PtS}_{2} / \mathrm{C}_{3} \mathrm{~N}_{4}$ heterostructure, the coefficient atoms in the chemical equation, and the chemical potential of atoms, respectively. In the case of $\mu_{O}$, it can be written as Equation (8):

$$
\mu_{i}=\mu^{0}(T)+k_{B} \operatorname{Tln}\left(\frac{p_{i}}{p^{0}}\right)
$$

where $\mu^{0}, k_{B}, T, p^{0}$, and $p_{i}$ are the standard chemical potential ( $\mathrm{p}_{0}=1$ bar), Boltzmann constant, temperature, standard partial pressure, and partial pressure, respectively. The standard chemical potential values were taken from the JANAF-NIST thermochemical table [53]. Using Equation (2) and Equation (6), the Gibbs energy for intercalation can be expressed as Equation (9):

$$
\Delta G_{f}=\Delta E_{D F T}+\Delta \mu_{0}\left(T, P_{0}\right)+k_{B} T \ln \left(K_{p}\right)
$$

where $\Delta E_{D F T}$ and $K_{p}$ are the change in total energies of the DFT and the equilibrium constant, respectively. Hence, $K_{p}$ is defined as Equation (10):

$$
K_{p}=e^{\left(\frac{\Delta G_{f}-\Delta E_{D F T}-\Delta \mu_{0}\left(T, P_{0}\right)}{k_{B} T}\right)}
$$


To consider the concentration of O-intercalation, the Boltzmann distribution is given by Equation (11)

$$
\frac{x_{p}}{x_{i}}=e^{\left(\frac{G_{i}-G_{p}}{k_{B} T}\right)}=e^{\left(\frac{\Delta G_{f}}{k_{B} T}\right)}
$$

where $x_{p}, x_{i}, G_{p}$, and $G_{i}$ denote the molar fraction of pristine and intercalation, and Gibbs free energy of pristine and intercalation in the $\mathrm{PtS}_{2} / \mathrm{C}_{3} \mathrm{~N}_{4}$ heterostructure, respectively.

Using Equations (10) and (11), $K_{p}$ is given by Equation (12)

$$
K_{p}=\frac{x_{p}}{x_{i}} \cdot e^{\left(\frac{-\Delta E_{D F T}-\Delta \mu_{0}\left(T, P_{0}\right)}{k_{B} T}\right)}
$$

The calculated $K_{p}$ was plotted for varying temperatures (Figure 4). It is known that $C_{3} N_{4}$ exhibits good crystallinity under the synthesis conditions between 873 and $973 \mathrm{~K}$ [58]. Therefore, to exclude other factors that affect the photocatalytic activity, other than O-intercalation, the temperature range for $\mathrm{K}_{\mathrm{P}}$ was set from $800 \mathrm{~K}$ to $1000 \mathrm{~K}$. When $\mathrm{O}_{2}$ gas is used as the reactant gas, the partial pressure of the $\mathrm{O}_{2}$ gas must be $2.83 \times 10^{21} \mathrm{~atm}$ at $800 \mathrm{~K}$ and $5.60 \times 10^{18}$ atm at $1000 \mathrm{~K}$ in order to insert $1 \mathrm{at} \% \mathrm{O}$. However, these partial pressures are much higher than the practical processing capabilities of synthesis devices. When $\mathrm{H}_{2} \mathrm{O}$ is the reactant gas for O-intercalation in the $\mathrm{PtS}_{2} / \mathrm{C}_{3} \mathrm{~N}_{4}$ heterostructure, the partial pressure of the $\mathrm{H}_{2}$ should be controlled between $6.3 \times 10^{-7} \mathrm{~atm}$ and $3.9 \times 10^{-6} \mathrm{~atm}$, which is a feasible range in synthesis devices. Through this result, it is expected that the $\mathrm{PtS}_{2} / \mathrm{O} / \mathrm{C}_{3} \mathrm{~N}_{4}$ heterostructure can be synthesized using $\mathrm{H}_{2} \mathrm{O}$ gas as the reactant gas.

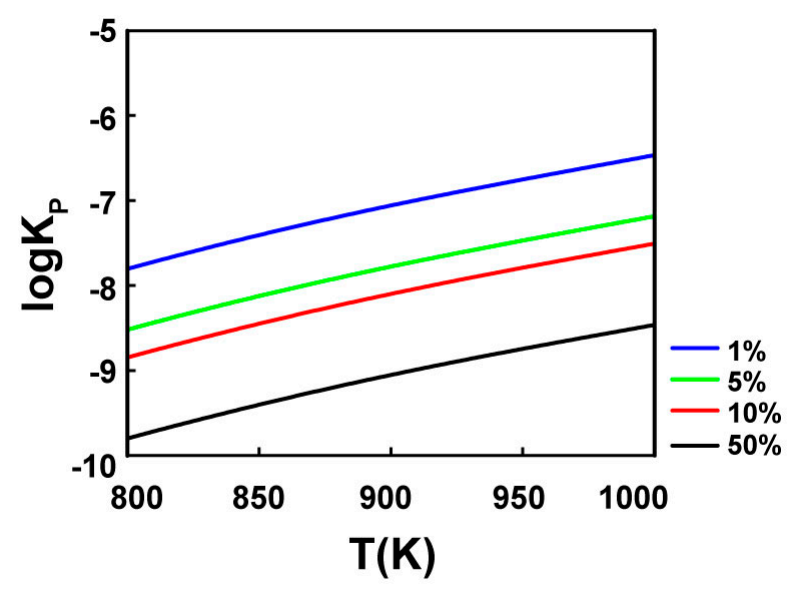

Figure 4. The $\mathrm{K}_{\mathrm{ps}}$ of the $\mathrm{PtS}_{2} / \mathrm{O}_{\mathrm{X}} / \mathrm{C}_{3} \mathrm{~N}_{4}(\mathrm{X}=1,5,10,50 \%)$ heterostructure expressed depending on the temperature for fabrication.

\section{Calculation Method}

All DFT calculations were performed with the Vienna Ab initio package (VASP) $[59,60]$. The interactions between the valence and core electrons were described using the projector augmented wave (PAW) method [61]. A generalized gradient approximation (GGA) with the Perdew-Burke-Ernzerhof (PBE) functional was employed for the plane-wave expansion with a cutoff energy of $500 \mathrm{eV}[62,63]$. Brillouin zones were sampled with a Monkhorst-Pack k-point grid of $2 \times 2 \times 1$ in the $4 \times 4 \mathrm{PtS}_{2} / \mathrm{C}_{3} \mathrm{~N}_{4}$ heterostructure with O-intercalation [64]. The energy convergence criteria in the self-consistent field were set to $10^{-5} \mathrm{eV}$. All geometry structures were fully relaxed until the Hellman-Feynman forces achieved a range of $0.02 \mathrm{eV}^{-1}$. The Methfessel-Paxton smearing scheme was applied with a smearing width of $0.1 \mathrm{eV}$ [65]. To avoid the artifact of a neighboring periodic image, the size of the vacuum region in the $\mathrm{z}$ direction was set to a value larger than $20 \AA$. The vdW correction was considered with Grimme's DFT-D3 (BJ) scheme to accurately describe the interaction between the $\mathrm{C}_{3} \mathrm{~N}_{4}$ and $\mathrm{PtS}_{2}$ 
layers [66]. The band gap of the $\mathrm{PtS}_{2} / \mathrm{C}_{3} \mathrm{~N}_{4}$ and $\mathrm{PtS}_{2} / \mathrm{O}_{X} / \mathrm{C}_{3} \mathrm{~N}_{4}(\mathrm{X}=1.8,3.6,5.4,7.1 \%)$ heterostructures were determined by the hybrid functional (HSE06) with $\alpha=0.2$ [67].

\section{Conclusions}

This study demonstrated that anion intercalation in a $2 \mathrm{D} / 2 \mathrm{D}$ heterostructure is an effective way to manipulate the direction and strength of the built-in electric fields and dipole moments. The direction of the vertical built-in electric field in the $\mathrm{PtS}_{2} / \mathrm{C}_{3} \mathrm{~N}_{4}$ heterostructure can be reversed with O-intercalation at the interface, as the $\mathrm{O}$-atom bound to the $\mathrm{PtS}_{2}$ accepts electrons and induces a local dipole moment in the opposite direction. When the O-intercalation density increased, the intensities of the electric field and dipole moment increased nearly linearly. It was also noticeable that the band edge levels in the $\mathrm{PtS}_{2}$ and the $\mathrm{C}_{3} \mathrm{~N}_{4}$ significantly shifted with different O-intercalation amounts. Hence, this anion intercalation method can be widely used for 2D/2D heterojunction photocatalysts for effective control of charge separation aspects and redox reactivities.

Supplementary Materials: The following are available online at http://www.mdpi.com/2073-4344/10/5/469/s1, Figure S1: The stable configuration of the $\mathrm{PtS}_{2} / \mathrm{O}_{\mathrm{x}} / \mathrm{C}_{3} \mathrm{~N}_{4}$ heterostructure $(\mathrm{x}=$ (a) $1.8,(\mathrm{~b}) 3.6$, (c) 5.4 , and (d) $7.1 \%$ ). The purple, yellow, blue, gray, and red color denote the $\mathrm{Pt}, \mathrm{S}, \mathrm{N}, \mathrm{C}$, and $\mathrm{O}$ atoms, respectively, Figure S2: The charge density difference and planar-averaged electron density difference for the $\mathrm{PtS}_{2} / \mathrm{O}_{3.6} / \mathrm{C}_{3} \mathrm{~N}_{4}, \mathrm{PtS}_{2} / \mathrm{O}_{5.4} \% / \mathrm{C}_{3} \mathrm{~N}_{4}$, $\mathrm{PtS}_{2} / \mathrm{O}_{7.1 \%} / \mathrm{C}_{3} \mathrm{~N}_{4}$ heterostructures. The purple, yellow, blue, gray, and red atoms indicate $\mathrm{Pt}, \mathrm{S}, \mathrm{N}, \mathrm{C}$, and $\mathrm{O}$, respectively. The yellow and cyan areas indicate charge accumulation and depletion, respectively. The iso-values are $0.005 \mathrm{eV} / \AA^{3}$, Figure S3: The band structure of the $\mathrm{PtS}_{2} / \mathrm{O}_{3.6} \% \mathrm{C}_{3} \mathrm{~N}_{4}, \mathrm{PtS} \mathrm{S}_{2} / \mathrm{O}_{5.4} \% / \mathrm{C}_{3} \mathrm{~N}_{4}$, and $\mathrm{PtS} \mathrm{S}_{2} / \mathrm{O}_{7.1 \%} / \mathrm{C}_{3} \mathrm{~N}_{4}$ heterostructures, respectively. The contribution of each monolayer in the band structure of the $\mathrm{PtS} \mathrm{S}_{2} / \mathrm{O}_{3.6 \%} / \mathrm{C}_{3} \mathrm{~N}_{4}$, $\mathrm{PtS}_{2} / \mathrm{O}_{5.4} / \mathrm{C}_{3} \mathrm{~N}_{4}$, and $\mathrm{PtS}_{2} / \mathrm{O}_{7.1 \%} / \mathrm{C}_{3} \mathrm{~N}_{4}$ heterostructures. The percentages of the contributions of each layer are marked in a different color. The Fermi level was set to zero, Figure S4: The projected density of states in the $\mathrm{PtS}_{2} / \mathrm{O}_{\mathrm{x}} / \mathrm{C}_{3} \mathrm{~N}_{4}(\mathrm{x}=0,1.8,3.6,5.4,7.1 \%)$ heterostructure. The black, blue, and red line indicate the $\mathrm{PtS}_{2}$ layer, $\mathrm{C}_{3} \mathrm{~N}_{4}$ layer, and $\mathrm{O}$ atom in the $\mathrm{PtS}_{2} / \mathrm{O}_{\mathrm{X}} / \mathrm{C}_{3} \mathrm{~N}_{4}$ heterostructure. The Fermi level (vertical black dotted line) was set to zero, Table S1: The intercalation energy of the $\mathrm{PtS}_{2} / \mathrm{O}_{\mathrm{x}} / \mathrm{C}_{3} \mathrm{~N}_{4}$ heterostructure $(\mathrm{x}=1.8,3.6,5.4,7.1 \%)$.

Author Contributions: Data curation, J.W.; Funding acquisition, H.C. and Y.-C.C.; Investigation, H.C. and Y.-C.C.; Software, E.S.S.; Visualization, M.J.; Writing - original draft, M.J.; Writing - review \& editing, H.C. and Y.-C.C. All authors have read and agreed to the published version of the manuscript.

Funding: This research was funded by the German Academic Exchange Service Deutscher Akademischer Austauschdienst (DAAD), grant number 57429784. This research was funded by the Ministry of Science, ICT, and Future Planning, grant number 2019R1A2B5B01070215.

Acknowledgments: M.J. and H.C. acknowledge the University of Cologne and the financial support of the Federal Ministry of Education and Research (BMBF) under the "Make Our Planet Great Again - German Research Initiative" (MOPGA-GRI), 57429784, implemented by the German Academic Exchange Service Deutscher Akademischer Austauschdienst (DAAD). E.S.S., J.W., and Y.-C.C. were supported by the National Research Foundation of Korea (NRF) grant funded by the Korea government (Ministry of Science and ICT) (2019R1A2B5B01070215).

Conflicts of Interest: The authors declare no conflicts of interest. The funders had no role in the design of the study; in the collection, analyses, or interpretation of data; in the writing of the manuscript, or in the decision to publish the results.

\section{References}

1. Toroker, M.C.; Kanan, D.K.; Alidoust, N.; Isseroff, L.Y.; Liao, P.; Carter, E.A. First principles scheme to evaluate band edge positions in potential transition metal oxide photocatalysts and photoelectrodes. Phys. Chem. Chem. Phys. 2011, 13, 16644-16654. [CrossRef] [PubMed]

2. Li, H.; Hu, H.; Bao, C.; Guo, F.; Zhang, X.; Liu, X.; Hua, J.; Tan, J.; Wang, A.; Zhou, H. Forming heterojunction: An effective strategy to enhance the photocatalytic efficiency of a new metal-free organic photocatalyst for water splitting. Sci. Rep. 2016, 6, 29327. [CrossRef] [PubMed]

3. Hisatomi, T.; Kubota, J.; Domen, K. Recent advances in semiconductors for photocatalytic and photoelectrochemical water splitting. Chem. Soc. Rev. 2014, 43, 7520-7535. [CrossRef] [PubMed]

4. Esswein, A.J.; Nocera, D.G. Hydrogen Production by Molecular Photocatalysis. Chem. Rev. 2007, 107, 4022-4047. [CrossRef]

5. Ngoh, S.K.; Njomo, D. An overview of hydrogen gas production from solar energy. Renew. Sustain. Energy Rev. 2012, 16, 6782-6792. [CrossRef] 
6. Saraf, S.; Giraldo, M.; Paudel, H.P.; Sakthivel, T.S.; Shepard, C.; Gupta, A.; Leuenberger, M.N.; Seal, S. Photoelectrochemical analysis of band gap modulated $\mathrm{TiO}_{2}$ for photocatalytic water splitting. Int. J. Hydrog. Energy 2017, 42, 9938-9944. [CrossRef]

7. Ikeda, S.; Fujikawa, S.; Harada, T.; Nguyen, T.H.; Nakanishi, S.; Takayama, T.; Iwase, A.; Kudo, A. Photocathode Characteristics of a Spray-Deposited $\mathrm{Cu}_{2} \mathrm{ZnGeS}_{4}$ Thin Film for $\mathrm{CO}_{2}$ Reduction in a $\mathrm{CO}_{2}$-Saturated Aqueous Solution. ACS Appl. Energy Mater. 2019, 2, 6911-6918. [CrossRef]

8. Zhou, R.; Guzman, M.I. $\mathrm{CO}_{2}$ Reduction under Periodic Illumination of ZnS. J. Phys. Chem. C 2014, 118, 11649-11656. [CrossRef]

9. Zhu, Z.; Kao, C.T.; Tang, B.H.; Chang, W.C.; Wu, R.J. Efficient hydrogen production by photocatalytic water-splitting using Pt-doped $\mathrm{TiO}_{2}$ hollow spheres under visible light. Ceram. Int. 2016, 42, 6749-6754. [CrossRef]

10. Zhang, J.; Zhou, P.; Liu, J.; Yu, J. New understanding of the difference of photocatalytic activity among anatase, rutile and brookite $\mathrm{TiO}_{2}$. Phys. Chem. Chem. Phys. 2014, 16, 20382-20386. [CrossRef]

11. Yan, J.; Wu, H.; Chen, H.; Pang, L.; Zhang, Y.; Jiang, R.; Li, L.; Liu, S.F. One-pot hydrothermal fabrication of layered $\beta-\mathrm{Ni}(\mathrm{OH})_{2} / \mathrm{g}-\mathrm{C}_{3} \mathrm{~N}_{4}$ nanohybrids for enhanced photocatalytic water splitting. Appl. Catal. B 2016, 194, 74-83. [CrossRef]

12. Hoque, M.D.A.; Guzman, M.I. Photocatalytic Activity: Experimental Features to Report in Heterogeneous Photocatalysis. Materials 2018, 11, 1990. [CrossRef] [PubMed]

13. Opoku, F.; Govender, K.K.; Sittert, C.G.C.E.V.; Govender, P.P. Understanding the mechanism of enhanced charge separation and visible light photocatalytic activity of modified wurtzite $\mathrm{ZnO}$ with nanoclusters of $\mathrm{ZnS}$ and graphene oxide: From a hybrid density functional study. New. J. Chem. 2017, 41, 8140-8155. [CrossRef]

14. Lahiri, J.; Batzill, M. Surface Functionalization of ZnO Photocatalysts with Monolayer ZnS. J. Phys. Chem. C 2008, 112, 4304-4307. [CrossRef]

15. Tahir, M.; Cao, C.; Mahmood, N.; Butt, F.K.; Mahmood, A.; Idrees, F.; Hussain, S.; Tanveer, M.; Ali, Z.; Aslam, I. Multifunctional g- $\mathrm{C}_{3} \mathrm{~N}_{4}$ Nanofibers: A Template-Free Fabrication and Enhanced Optical, Electrochemical, and Photocatalyst Properties. ACS Appl. Mater. Interfaces 2014, 6, 1258-1265. [CrossRef]

16. Xu, Y.; Fu, Z.C.; Cao, S.; Chen, Y.; Fu, W.F. Highly selective oxidation of sulfides on a $\mathrm{CdS} / \mathrm{C}_{3} \mathrm{~N}_{4}$ catalyst with dioxygen under visible-light irradiation. Catal. Sci. Technol. 2017, 7, 587-595. [CrossRef]

17. Wang, X.C.; Maeda, K.; Thomas, A.; Takanabe, K.; Xin, G.; Carlsson, J.M.; Domen, K.; Antonietti, M. A metal-free polymeric photocatalyst for hydrogen production from water under visible light. Nat. Mater. 2009, 8, 76-80. [CrossRef]

18. Zhang, W.; Sun, Y.; Dong, F.; Zhang, W.; Duan, S.; Zhang, Q. Facile synthesis of organic-inorganic layered nanojunctions of $\mathrm{g}-\mathrm{C}_{3} \mathrm{~N}_{4} /(\mathrm{BiO})_{2} \mathrm{CO}_{3}$ as efficient visible light photocatalyst. Dalton Trans. 2014, 43, 12026-12036. [CrossRef]

19. Zhang, G.; Lan, Z.A.; Lin, L.; Lin, S.; Wang, X. Overall water splitting by Pt/g- $\mathrm{C}_{3} \mathrm{~N}_{4}$ photocatalysts without using sacrificial agents. Chem. Sci. 2016, 7, 3062-3066. [CrossRef]

20. Liu, J.; Cheng, B.; Yu, J. A new understanding of the photocatalytic mechanism of the direct Z-scheme g- $\mathrm{C}_{3} \mathrm{~N}_{4} / \mathrm{TiO}_{2}$ heterostructure. Phys. Chem. Chem. Phys. 2018, 18, 31175-31183. [CrossRef]

21. Liu, J.; Jia, Q.; Long, J.; Wang, X.; Gao, Z.; Gu, Q. Amorphous $\mathrm{NiO}$ as co-catalyst for enhanced visible-light-driven hydrogen generation over $\mathrm{g}-\mathrm{C}_{3} \mathrm{~N}_{4}$ photocatalyst. Appl. Catal. B 2018, 222, 35-43. [CrossRef]

22. Su, T.; Shao, Q.; Qin, Z.; Guo, Z.; Wu, Z. Role of Interfaces in Two-Dimensional Photocatalyst for Water Splitting. ACS Catal. 2018, 8, 2253-2276. [CrossRef]

23. Li, H.; Yu, H.; Quan, X.; Chen, S.; Zhang, Y. Uncovering the Key Role of the Fermi Level of the Electron Mediator in a Z-Scheme Photocatalyst by Detecting the Charge Transfer Process of $\mathrm{WO}_{3}$-metal-gC $\mathrm{N}_{4}$ (Metal = Cu, Ag, Au). ACS Appl. Mater. Interfaces 2016, 8, 2111-2119. [CrossRef] [PubMed]

24. Cai, X.; Zhang, J.; Fujitsuka, M.; Majima, T. Graphitic- $\mathrm{C}_{3} \mathrm{~N}_{4}$ hybridized N-doped $\mathrm{La}_{2} \mathrm{Ti}_{2} \mathrm{O}_{7}$ two-dimensional layered composites as efficient visible-light-driven photocatalyst. Appl. Catal. B 2017, 202, 191-198. [CrossRef]

25. Scanlon, D.O.; Dunnill, C.W.; Buckeridge, J.; Shevlin, S.A.; Logsdail, A.J.; Woodley, S.M.; Catlow, C.R.A.; Powell, M.J.; Palgrave, R.G.; Parkin, I.; et al. Band alignment of rutile and anatase $\mathrm{TiO}_{2}$. Nat. Mater. 2013, 12, 798-801. [CrossRef]

26. Khan, S.; Cho, H.; Kim, D.; Han, S.S.; Lee, K.H.; Cho, S.H.; Song, T.; Choi, H. Defect engineering toward strong photocatalysis of $\mathrm{Nb}$-doped anatase $\mathrm{TiO}_{2}$ : Computational predictions and experimental verifications. Appl. Catal. B 2017, 206, 520-530. [CrossRef] 
27. Zhang, J.; Zhang, M.; Sun, R.Q.; Wang, X. A facile band alignment of polymeric carbon nitride semiconductors to construct isotype heterojunctions. Angew. Chem. 2012, 51, 10145-10149. [CrossRef]

28. Wang, X.; Xu, Q.; Li, M.; Shen, S.; Wang, X.; Wang, Y.; Feng, Z.; Shi, J.; Han, H.; Li, C. Photocatalytic overall water splitting promoted by an $\alpha-\beta$ phase junction on $\mathrm{Ga}_{2} \mathrm{O}_{3}$. Angew. Chem. 2012, 51, 13089-13092. [CrossRef]

29. Hu, S.; Ma, L.; Li, F.; Fan, Z.; Wang, Q.; Bai, J.; Kang, X.; Wu, G. Construction of g-C $\mathrm{C}_{3} \mathrm{~N}_{4} / \mathrm{S}-\mathrm{g}-\mathrm{C}_{3} \mathrm{~N}_{4}$ metal-free isotype heterojunctions with an enhanced charge driving force and their photocatalytic performance under anoxic conditions. RSC Adv. 2015, 5, 90750-90756. [CrossRef]

30. Li, J.; Zhang, Z.; Cui, W.; Wang, H.; Cen, W.; Johnson, G.; Jiang, G.; Zhang, S.; Dong, F. The Spatially Oriented Charge Flow and Photocatalysis Mechanism on Internal van der Waals Heterostructures Enhanced g- $\mathrm{C}_{3} \mathrm{~N}_{4}$. ACS Catal. 2018, 8, 8376-8385. [CrossRef]

31. Chen, L.; Shi, G.; Shen, J.; Peng, B.; Zhang, B.; Wang, Y.; Bian, F.; Wang, J.; Li, D.; Qian, Z.; et al. Ion sieving in graphene oxide membranes via cationic control of interlayer spacing. Nature 2017, 550, 380-383. [CrossRef] [PubMed]

32. Ditto, J.; Merrill, D.R.; Mitchson, G.; Gabriel, J.J.; Mathew, K.; Hennig, R.G.; Medlin, D.L.; Browning, N.D.; Johnson, D.C. Interface-Driven Structural Distortions and Composition Segregation in Two-Dimensional Heterostructure. Angew. Chem. 2017, 56, 14448-14452. [CrossRef] [PubMed]

33. Xiong, T.; Cen, W.; Zhang, Y.; Dong, F. Bridging the $\mathrm{g}-\mathrm{C}_{3} \mathrm{~N}_{4}$ Interlayers for Enhanced Photocatalysis. ACS Catal. 2016, 6, 2462-2472. [CrossRef]

34. Qu, X.; Hu, S.; Bai, J.; Lu, G.; Kang, X. A facile approach to synthesize oxygen doped g- $\mathrm{C}_{3} \mathrm{~N}_{4}$ with enhanced visible light activity under anoxic conditions via oxygen-plasma treatment. New J. Chem. 2018, 42, 4998-5004. [CrossRef]

35. Li, J.H.; Shen, B.; Hong, Z.; Lin, B.; Gao, B.; Chen, Y. A facile approach to synthesize novel oxygen-doped g- $\mathrm{C}_{3} \mathrm{~N}_{4}$ with superior visible-light photoreactivity. Chem. Commum. 2012, 48, 12017-12019. [CrossRef] [PubMed]

36. Han, B.; Hu, Y.H. $\mathrm{MoS}_{2}$ as a co-catalyst for photocatalytic hydrogen production from water. Energy Sci. Eng. 2016, 4, 285-304. [CrossRef]

37. Wei, L.; Chen, Y.; Lin, Y.; Wu, H.; Yuan, R.; Li, Z. MoS 2 as non-noble-metal co-catalyst for photocatalytic hydrogen evolution over hexagonal ZnIn2S4 under visible light irradiations. Appl. Catal. B 2014, 144, 521-527. [CrossRef]

38. Zhang, W.; Xiao, X.; Zeng, X.; Li, Y.; Zheng, L.; Wan, C. Enhanced photocatalytic activity of $\mathrm{TiO}_{2}$ nanoparticles using $\mathrm{SnS}_{2} /$ RGO hybrid as co-catalyst: DFT study and photocatalytic mechanism. J. Alloys Comd. 2016, 685, 774-783. [CrossRef]

39. Akple, M.S.; Low, J.; Wageh, S.; Al-Ghamdi, A.A.; Yu, J.; Zhang, J. Enhanced visible light photocatalytic H2-production of g- $\mathrm{C}_{3} \mathrm{~N}_{4} / \mathrm{WS}_{2}$ composite heterostructures. Appl. Surf. Sci. 2015, 358, 196-203. [CrossRef]

40. Yan, J.; Chen, Z.; Ji, H.; Liu, Z.; Wang, X.; Xu, Y.; She, X.; Huang, L.; Xu, L.; Xu, H.; et al. Construction of a $2 \mathrm{D}$ Graphene-Like $\mathrm{MoS}_{2} / \mathrm{C}_{3} \mathrm{~N}_{4}$ Heterojunction with Enhanced Visible-Light Photocatalytic Activity and Photoelectrochemical Activity. Chemistry 2016, 22, 4764-4773. [CrossRef]

41. Wang, J.; Guan, Z.; Huang, J.; Li, Q.; Yang, J. Enhanced photocatalytic mechanism for the hybrid g-C $\mathrm{N}_{4} / \mathrm{MoS}_{2}$ nanocomposite. J. Mater. Chem. A 2014, 2, 7960-7966. [CrossRef]

42. Liu, J.; Hua, E. High Photocatalytic Activity of Heptazine-Based g- $\mathrm{C}_{3} \mathrm{~N}_{4} / \mathrm{SnS}_{2}$ Heterojunction and Its Origin: Insights from Hybrid DFT. J. Phys. Chem. C 2017, 121, 25827-25835. [CrossRef]

43. Mir, S.H.; Chakraborty, S.; Wärnå, J.; Narayan, S.; Jha, P.C.; Jha, P.K.; Ahuja, R. A comparative study of hydrogen evolution reaction on pseudo-monolayer $\mathrm{WS}_{2}$ and $\mathrm{PtS}_{2}$ : Insights based on the density functional theory. Catal. Sci. Technol. 2017, 7, 687-692. [CrossRef]

44. Chia, X.; Adriano, A.; Lazar, P.; Sofer, Z.; Luxa, J.; Pumera, M. Layered Platinum Dichalcogenides $\left(\mathrm{PtS}_{2}\right.$, $\mathrm{PtSe}_{2}$, and $\mathrm{PtTe}_{2}$ ) Electrocatalysis: Monotonic Dependence on the Chalcogen Size. Adv. Funct. Mater. 2016, 26, 4306-4318. [CrossRef]

45. Li, L.; Wang, W.; Chai, Y.; Li, H.; Tian, M.; Zhai, T. Few-Layered PtS 2 Phototransistor on h-BN with High Gain. Adv. Funct. Mater. 2017, 27, 1701011. [CrossRef]

46. Zhang, K.; Hu, S.; Zhang, Y.; Zhang, T.; Zhou, X.; Sun, Y.; Li, T.X.; Fan, H.J.; Shen, G.; Chen, X.; et al. Self-Induced Uniaxial Strain in $\mathrm{MoS}_{2}$ Monolayers with Local van der Waals-Stacked Interlayer Interactions. ACS Nano 2015, 9, 2704-2710. [CrossRef] 
47. Jiang, J.W.; Park, H. Mechanical properties of $\mathrm{MoS}_{2} /$ graphene heterostructure. Appl. Phys. Lett. 2014, 105, 033108. [CrossRef]

48. Huang, Z.F.; Song, J.; Pan, L.; Wang, Z.; Zhang, X.; Zou, J.J.; Mi, W.; Zhang, X.; Wang, L. Carbon nitride with simultaneous porous network and O-doping for efficient solar-energy-driven hydrogen evolution. Nano Energy 2015, 12, 646-656. [CrossRef]

49. Björkman, T.; Gulans, A.; Krasheninnikov, A.V.; Nieminen, R.M. van der Waals Bonding in Layered Compounds from Advanced Density-Functional First-Principles Calculations. Phys. Rev. Lett. 2012, 108, 235502. [CrossRef]

50. Liao, J.; Sa, B.; Zhou, J.; Ahuja, R.; Sun, Z. Design of High-Efficiency Visible-Light Photocatalysts for Water Splitting: $\mathrm{MoS}_{2} / \mathrm{AlN}(\mathrm{GaN})$ Heterostructures. J. Phys. Chem. C 2014, 118, 17594-17599. [CrossRef]

51. Huang, H.; Song, Z.; Wei, N.; Shi, L.; Mao, Y.; Ying, Y.; Sun, L.; Xu, Z.; Peng, X. Ultrafast viscous water flow through nanostrand-channelled graphene oxide membranes. Nat. Commun. 2013, 4, 2979. [CrossRef] [PubMed]

52. Baxter, J.B.; Richter, C.; Schmuttenmaer, C. Ultrafast Carrier Dynamics in Nanostructures for Solar Fuels. Annu. Rev. Phys. Chem. 2014, 65, 423-447. [CrossRef] [PubMed]

53. Takanabe, K. Solar Water Splitting Using Semiconductor Photocatalyst Powders. In Solar Energy for Fuels; Springer: Cham, Switzerland, 2015; pp. 73-103.

54. Li, M.; Dai, Y.; Ma, X.; Li, Z.; Huang, B. The synergistic effect between effective mass and built-in electric field for the transfer of carriers in nonlinear optical materials. Phys. Chem. Chem. Phys. 2015, 17, 17710-17717. [CrossRef] [PubMed]

55. Fang, Q.; Zhao, X.; Huang, Y.; Xu, K.; Min, T.; Chu, P.K.; Ma, F. Interfacial electronic states and self-formed p-n junctions in hydrogenated $\mathrm{MoS}_{2} / \mathrm{SiC}$ heterostructure. J. Mater. Chem. C 2018, 6, 4523-4530. [CrossRef]

56. Zhang, X.; Shen, J.X.; Wang, W.; Van de Walle, C.G. First-Principles Analysis of Radiative Recombination in Lead-Halide Perovskites. ACS Eng. Lett. 2018, 3, 2329-2334. [CrossRef]

57. Gao, G.; Jiao, Y.; Ma, F.; Jiao, Y.; Waclawik, E.; Du, A. Carbon nanodot decorated graphitic carbon nitride: New insights into the enhanced photocatalytic water splitting from ab initio studies. Phys. Chem. Chem. Phys. 2015, 17, 31140-31144. [CrossRef]

58. Mo, Z.; She, X.; Li, Y.; Liu, L.; Huang, L.; Chen, Z.; Zhang, Q.; Xu, H.; Li, H. Synthesis of g-C ${ }_{3} \mathrm{~N}_{4}$ at different temperatures for superior visible/UV photocatalytic performance and photoelectrochemical sensing of $\mathrm{MB}$ solution. RSC. Adv. 2015, 5, 101552-101562. [CrossRef]

59. Kresse, G.; Furthmüller, J. Efficiency of ab-initio total energy calculations for metals and semiconductors using a plane-wave basis set. Comput. Mater. Sci. 1996, 6, 15-50. [CrossRef]

60. Kresse, G.; Furthmüller, J. Efficient iterative schemes for ab initio total-energy calculations using a plane-wave basis set. Phys. Rev. B 1996, 54, 11169. [CrossRef]

61. Kresse, G.; Joubert, D. From ultrasoft pseudopotentials to the projector augmented-wave method. Phys. Rev. $B$ 1999, 59, 1758. [CrossRef]

62. Perdew, J.P.; Chevary, J.A.; Vosko, S.H.; Jackson, K.A.; Pederson, M.R.; Singh, D.J.; Fiolhais, C. Atoms, molecules, solids, and surfaces: Applications of the generalized gradient approximation for exchange and correlation. Phys. Rev. B 1992, 46, 6671. [CrossRef] [PubMed]

63. Perdew, J.P.; Burke, K.; Ernzerhof, M. Generalized Gradient Approximation Made Simple. Phys. Rev. Lett. 1996, 77, 3865. [CrossRef]

64. Monkhorst, H.J.; Pack, J.D. Special points for Brillouin-zone integrations. Phys. Rev. B 1976, 13, 5188. [CrossRef]

65. Methfessel, M.; Paxton, A. High-precision sampling for Brillouin-zone integration in metals. Phys. Rev. B 1989, 40, 3616. [CrossRef] [PubMed]

66. Grimme, S.; Ehrlich, S.; Goerigk, L. Effect of the damping function in dispersion corrected density functional theory. J. Comput. Chem. 2011, 32, 1456-1465. [CrossRef]

67. Heyd, J.; Scuseria, G.E.; Ernzerhof, M. Hybrid functionals based on a screened Coulomb potential. J. Chem. Phys. 2003, 118, 8207-8215. [CrossRef]

(C) 2020 by the authors. Licensee MDPI, Basel, Switzerland. This article is an open access article distributed under the terms and conditions of the Creative Commons Attribution (CC BY) license (http://creativecommons.org/licenses/by/4.0/). 